\title{
Silica gel chromatographic study of phenolic compounds in some cultivated cucurbits
}

\author{
Suresh N Baitha* and Vijoy S Pandey \\ Botany Department, Mahanth Sheo Shankar Giri College, Baba Sahab Bhim Rao Ambedkar Bihar University, Muzaffarpur, \\ Areraj 845411, India \\ * Towhom correspondenceshould beaddressed. E-mail:snbaitha2000@yahoo.co.in
}

Phenolic compounds in the leaves of cultivated cucurbits viz. Trichosanthes dioica Roxb., Lagenaria siceraria (Molina) Standl., Luffa cylindrica (L.) Roem., and Luffa acutangula(L.) Roxb. were carried out through silica gel chromatographic separation to ascertain their relative phylogenetic position. On phytochemical analysis, paired affinity, group affinity and isolation value supported the inclusion of these species in the same tribe Cucurbiteae on the basis of earlier cytotaxonomic studies. The two species of Luffa showed the closest phytochemical affinity and occupied as intermediate position between Lagenariaand Trichosanthes. Luffaw as distantly related to other two genera having paired affinity values of less than $50 \%$.

Key words: Silica gel chromatography, separation of phenolic compounds, cultivated cucurbits

Him J Sci 1(2): 123-125

URL: www.himjsci.com/issue2/ cucurbits

Received: 21 Nov 2002

Accepted after revision: 20 June 2003

\begin{abstract}
Introduction
Thesecondarymetabolitessuch as alkaloids, terpenesand phenolics includingflavonoidscan beemployed tostudyphylogenetic affinitiy in many plant genera. Thethin layer chromatography wasemployed successfully for the separation of phenolic compoundsin a number of generalikeSecale(Frost 1966, Dedio etal. 1969), Aegilops(Kaltsikes and Dedio 1970), Hordeum and Triticum (Frost and Holm 1973), Cucumerineae (Das et al. 1974) etc. for substantiating earlier conclusions drawn on the status of their taxa on the basis of cytogenetic evidence. Among the earlier reports of chemosystematics in the Cucurbitaceae, Enslin and Rehm (1958) used the distribution of cucurbitacinsasan index in thetaxonomy of the Cucurbitaceae. On thebasis of distribution of phenolics, Das etal. (1974) concluded that Citrullusvul garishad closer relationship with Lagenaria than Citrullusvulgarisvar fistulosusand suggested the possible evolution of Citrullus vulgaris from Lagenaria or vice-versa. They also showed the close relationship between Lagenaria and Luffa.

Thepresent investigation on thedistribution of phenolics was carried out in four morphologically related species of cucurbits to examinetheir relative phyletic distanceas evidenced from their biochemical picture.
\end{abstract}

\section{Materials and methods}

Four species of cucurbits viz. Trichosanthesdioica Roxb., Lagenaria siceraria (Molina) Standl., Luffa cylindrica (L.) Roxb. and Luffa acutangula (L.) Roxb. were studied in the present investigation. The leaves from the apical portion of all the species of same age were collected for biochemical assay. The leaves were first washed thoroughlyin runningtap water and dried at $40^{\circ} \mathrm{C}$ in an oven for 24 hrs. Theleaves werecrushed and kept in a $50 \%$ solution of pertoleum ether (BP $40-60^{\circ} \mathrm{C}$ ) and aqueous methanol for $24 \mathrm{hrsin}$ order to get phenolic extracts. Each extract, on evaporation under vacuum pump, yields a sticky residue.

A chromatographic plate was prepared with silica gel. 0.1 $\mathrm{ml}$ aqueous methanolic extract was applied at thestarting point of the plate. It was then dipped in the solvent TCA (toluenechloroform-acetone) and allowed to develop chromatogram. The chromatogram was first treated with ammonia vapour, then with iodine vapour and finally with $1 \%$ lead acetateas recommended by Block et al. (1953) to distinguish the spots. Ammonia vapour gave distinct colour under visibleand UV light in case of somephenolic spots. The spots of other phenolic compounds became apparent after treatment with iodine vapour and lead acetate. The visible spots weretraced on atransparent paper. TheRF (relativedistance) of each spot was used as a basis for comparison and specification of various phenolic compounds obtained. On the basis of colour and position, spotsassumed to beindentical in two or morespecies wereassigned thesamenumber. Thechromatographic resultswere subjected to numerical taxonomic treatment as an aid to establish phenolic relationship in the different species of the family Cucurbitaceae.

\section{Analysis of phytochemical data}

The method adopted by Ellison et al. (1962) was followed to make the suitable comparisons in the form of qualitative relationships. Species werecompared on thebasis of their biochemical affinityies. Values of paired affinity (PA), group affinity (GA) and isolation value (IV) were calculated as follows:

$$
\begin{aligned}
& \mathrm{PA}=\frac{\text { Spots common in species } A \text { and } B}{\text { Total spots in } A \text { and } B} \times 100 \\
& \mathrm{GA}=\text { Total PA value }+100 \\
& \mathrm{IV}=\frac{\text { Number of unique spots in a species }}{\text { Total number of spots in all species }} \times 100
\end{aligned}
$$

\section{Results}

Thetotal number of spots obtained in all thespecies was 20, out of which eight were found in T. dioica, nine in L. siceraria, eight in L. 
cylindrica and nine in L. acutangula (Figure 1). From the observation of the composite chromatogram it was distinct that $L$. cylindrica and L. acutangula had six spots in common. A relative distribution of all the spots has been shown in Table 1

The PA value calculated on the basis of presence and absence of the phenolics is shown in Table 2 Thehighest PA value $70.68 \%$ was observed between L. cylindrica and L. acutangula. The lowest PA value (25\%) was found between $L$. cylindrica and $L$. siceraria. The PA value between T. dioica and L. siceraria was $35.29 \%$. These values showed that two species of Luffa wereclosely related but showed a distant relationship with both $\mathrm{T}$. dioica and $\mathrm{L}$. siceraria. Above observations showed the intermediate position of Luffa species between L. siceraria and T. dioica.

Group affinity values also showed the close relationship between L. cylindrica (230.57) and L. acutangula (230.31). The Luffa species werealso related to L. siceraria (215.02) on onehand and T. dioica (195.58) on the other (Table 3).

The isolation valuewas found to be $20 \%$ each in T. dioica and L. siceraria while for L. cylindrica and L. acutangula it was just half i.e. 10\% (Table 3).

\section{Discussion}

Although phenolics are considered to be metabolically inert, they are present in the cell wall of plants in considerable amounts and are stable and characteristic end products (Bate-Smith 1958). In the present investigation a number of phenolic compounds were spotted but they werenotidentified qualitatively. Chromatographic spots are regarded as excellent markers and are much more important than the chromosome numbers in taxonomy of plants (Grant 1968).

In thepresentstudyspotno 4 waspresentin all thespecies and appeared to bethecharacteristic spot for all the 4 species. Spot no 20 was found in three species viz. L. siceraria, L. cylindrica and L. acutangula. Its absence in T. dioica indicated that in comparison to T. dioica, L. siceraria was closer to the Luffa spp.

Higher PA value was considered as an indication of close affinity between different species. PA value of $50 \%$ and above was considered as a marker of close relationship. In this regard, the two species of Luffa (with PAvalue of $70.58 \%$ ) weremost closely related and appeared distantly related with Lagenaria and Trichosanthes conforming the conclusions drawn from cytotaxonomy.

ThePA valuewassupported bythe GA value, on the basis of which it could be said that $\mathrm{T}$. dioica was distantly related to the other species; L. cylandrica and L. acutangula were very close and showed some closeness to Lagenaria siceraria.

According to Ayyangar (1967), on the basis of a number of criteria like chromosome number, chromosome morphology, meiotic behaviour, secondary association, satellites, nucleoli, chiasma statistics, developmental morphology, amino acid assay, geographical distribution pattern

Colour of the spots: $\mathrm{BI}$ : Blue, Or: Orange, Gr: Green, Vi: Violet, Ye: Yellow

Reagents used: a: ammonia, b: iodine, c: $1 \%$ lead acetate

Concentration of the spots: $+1+$ more intense, +less intense, +trace, - absent

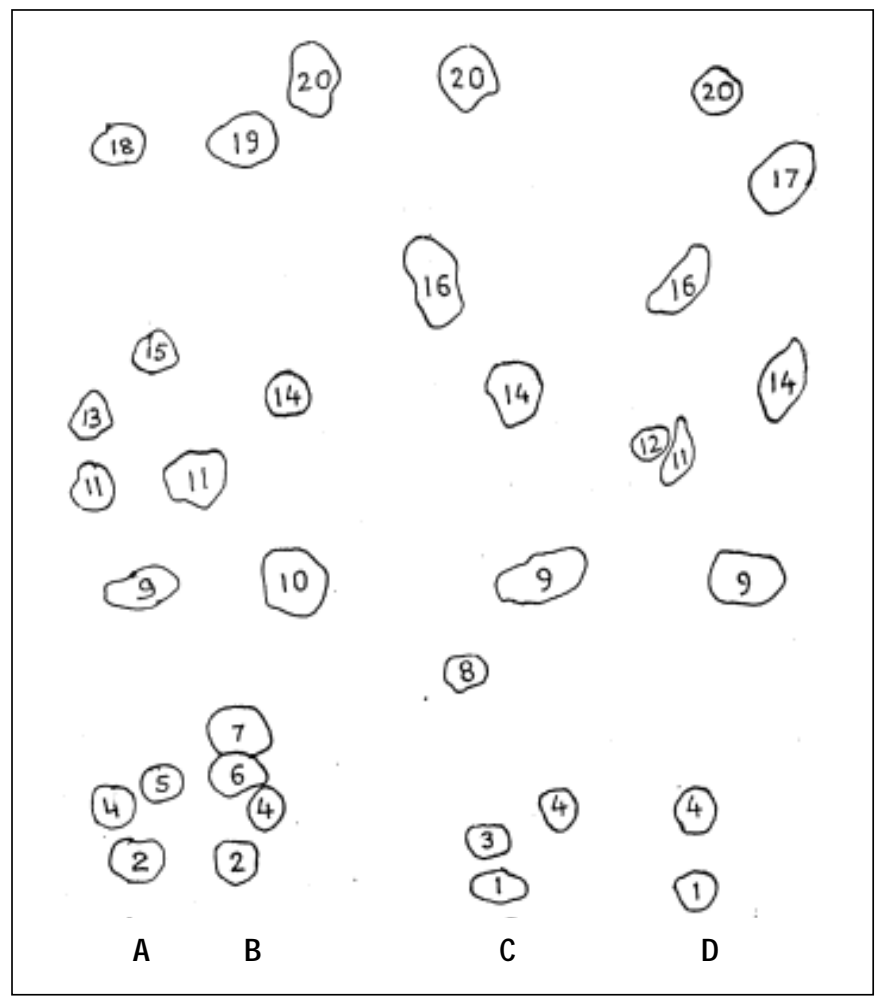

FIGURE 1. A composite chromatogram showing distribution of phenolic compound in
A - Trichosanthes dioica
B - Lagenaria siceraria
C - Luffa cylindrica
D - Luffa acutangula

TABLE 1. Thin layer chromatographic separation of phenolics in four cucurbits revealing colour of spots, their RF values and concentration

\begin{tabular}{lllllll}
\hline SN & Colour & $\begin{array}{l}\text { RF } \\
\text { values } \\
\text { T/C/A }\end{array}$ & $\begin{array}{l}\text { Tricosanthes } \\
\text { dioica }\end{array}$ & $\begin{array}{l}\text { Lagenaria } \\
\text { ciceraria }\end{array}$ & $\begin{array}{l}\text { Luffa } \\
\text { cylindrica }\end{array}$ & $\begin{array}{l}\text { Luffa } \\
\text { acutangula }\end{array}$ \\
\hline 1 & $\mathrm{Bl}(\mathrm{c})$ & 0.032 & - & - & + & + \\
\hline 2 & $\mathrm{Ye}(\mathrm{c})$ & 0.054 & + & + & - & - \\
\hline 3 & $\mathrm{Ye}(\mathrm{c})$ & 0.075 & - & - & + & - \\
\hline 4 & $\mathrm{Bl}(\mathrm{c})$ & 0.108 & +++ & + & + & ++ \\
\hline 5 & $\mathrm{Vi}(\mathrm{b})$ & 0.118 & ++ & - & - & - \\
\hline 6 & $\mathrm{Gr}(\mathrm{c})$ & 0.140 & - & + & - & - \\
\hline 7 & $\mathrm{Or}(\mathrm{a})$ & 0.182 & - & + & - & - \\
\hline 8 & $\mathrm{Bl}(\mathrm{c})$ & 0.254 & - & - & + & - \\
\hline 9 & $\mathrm{Vi} \mathrm{(b)}$ & 0.351 & + & - & + & + \\
\hline 10 & $\mathrm{Or}(\mathrm{a})$ & 0.356 & - & + & - & - \\
\hline 11 & $\mathrm{Ye}(\mathrm{c})$ & 0.464 & ++ & + & - & + \\
\hline 12 & $\mathrm{Ye}(\mathrm{c})$ & 0.491 & - & - & - & + \\
\hline 13 & $\mathrm{Bl}(\mathrm{c})$ & 0.497 & + & - & - & - \\
\hline 14 & $\mathrm{Ye}(\mathrm{c})$ & 0.545 & - & + & ++ & + \\
\hline 15 & $\mathrm{Or}(\mathrm{c})$ & 0.556 & + & - & - & - \\
\hline 16 & $\mathrm{Or}(\mathrm{a})$ & 0.659 & - & - & + & + \\
\hline 17 & $\mathrm{Vi} \mathrm{(b)}$ & 0.767 & - & - & - & + \\
\hline 18 & $\mathrm{Ye}(\mathrm{c})$ & 0.778 & + & - & - & - \\
\hline 19 & $\mathrm{Or}(\mathrm{a})$ & 0.806 & - & + & - & + \\
\hline 20 & $\mathrm{Vi}(\mathrm{b})$ & 0.875 & - & + & + & + \\
\hline & & & & & + & + \\
\hline
\end{tabular}


in conjuction with conventional morphological characters a system is proposed in which Trichosanthes, Luffa and Lagenaria were placed in the same tribe Cucurbiteae and were closely related, with Luffa occupying intermediate position between Trichosanthes on one hand and Lagenaria on the other. The distribution of phenolic compounds as reveled in the presentstudyalso supportstheclassification and phylogeny suggested by Ayyangar (1967).

It has been mentioned by Griesbach (1972) that the presence and concentration of given substance depend on the physiological growth condition of a plant and on itsstage of the development. It was found that the same chromatographic patterns of the flavonoids from the leaves of one and the same plant varied with age and environment (Harborne1967, Armstrong 1968, Parks et al. 1972). Therefore, the most suitable leaves for the study of phenolic compounds were considered the apical leaves obtained from the plants of sameage.

\section{References}

ArmstrongSM. 1968. Effectof potassium, magnesiumand nitrogen deficiencies on the chlorogenic acid in tobacco [abstract]. Diss Abstr. Abstract no 2311B. p29

Ayyangar KR. 1967. Taxonomy of Cucurbitaceae. Bull Natl Inst Sci Ind 34: 380-96

Bate-SmithEC. 1958. Plantphenolicsastaxonomic guide Proc Linn Soc Lond 169(3): 198-210

Block RJ, EL Durram and G Zoreig. 1958. A manual of paper chromatographyand paper edectrophoresis, 2nd ed. New York: Academic press. 710p

Das HC, GS Randawa and M Kaur. 1974. Phylogenetic studies in Cucumerinae by leaf phenolics. The NudeusXMI(II): 103-8

Dedio W, PS Kaltsikes and EN Larter. 1969. A thin layer

TABLE 2. Paired affinity value (PA) of different species

\begin{tabular}{|l|l|l|l|}
\hline & Tricosanthes dioica & Lagenaria siceraria & Luffa cylindrica \\
\hline $\begin{array}{l}\text { Lagenaria } \\
\text { siceraria }\end{array}$ & $35.29 \%$ & & \\
\hline $\begin{array}{l}\text { Luffa } \\
\text { cylindrica }\end{array}$ & $25 \%$ & $35.29 \%$ & $70.58 \%$ \\
\hline $\begin{array}{l}\text { Luffa } \\
\text { acutangula }\end{array}$ & $35.29 \%$ & $44.44 \%$ & \\
\hline
\end{tabular}

TABLE 3. Group affinity, number of unique spots and isolation value of phenolic compounds in cucurbits

\begin{tabular}{|l|l|l|l|}
\hline Species & GA & $\begin{array}{l}\text { No of unique } \\
\text { spots }\end{array}$ & $\begin{array}{l}\text { Isolation value } \\
\text { (\%) }\end{array}$ \\
\hline Tricosanthes dioica & 195.58 & 4 & 20 \\
\hline Lagenaria siceraria & 215.02 & 4 & 20 \\
\hline Luffa cylindrica & 230.57 & 2 & 10 \\
\hline Luffa acutangula & 250.31 & 2 & 10 \\
\hline
\end{tabular}

chromatographic study of the phenolsin Triticale and its parents. Can J Bot 47: 1589

EllisonWL, RE Alston and BL Turner. 1962. Methods of presentation of crude biochemical data for systematic purposes with particular reference to the genus Bahia (Compositae). Am J Bot 49: 599604

Enslin PR and S Rehm. 1958. The distribution and biogenesis of the cucurbitacins in relation to taxonomy of theCucurbitaceae. ProcLinn SocLond 169(3): $230-8$

FrostSand G Holm. 1973. Thin layer chromatographic studies of phenolic compounds in twenty varieties of barley. Hereditas 74(2): 304

Frost S. 1966. Variation of phenolic compounds in different inbred lines of rye. Hereditas 55: 68-72 Grant WF. 1968. Botanical editors and biochemical systematics. Chem Taxon 17: 159-60

Griesbach H. 1972. Comparativebiosynthetic pathways in higher plants. Chem Taxon Newslett 186

Harborne JB. 1967. Comparative biochemistry of the flavenoids. New York: Academic Press. 383p

Kaltsikes PJ and W Dedio. 1970. A thin layer chromatographic study of thephenolics of thegenus Aegilopsl:Numerical taxonomy of thediploid species. Can J Bot 43(10): 1775-80

ParksCR, SSSandhu and KR Montogometry. 1972. Floral pigmentation studies in the genus Gossypium IV: Effects of different growing environments on flavonoid pigmentation. AmJ Bot 58: 158-64 